\title{
THE ROLE OF THE SKELETON IN EGG-SHELL FORMATION
}

\author{
T.-G. TAYLOR (1) \\ Agricultural Research Council's Poultry Research Centre, \\ King's Buildings, West Mains Road, Edinburgh 9 (Great-Britain)
}

The relationship between skeletal metabolism and egg-shell formation has been reviewed on a number of occasions in recent years (SIMkiss, I96I, I967; TAYLOR and STRINGER, I965) and this review will concentrate on some aspects of the relationship which are less well understood, and for which new information is available.

The role of the skeleton of the laying bird in acting as a reserve of calcium when the rate at which the mineral is deposited on the shell exceeds the rate at which it is absorbed from the intestinal tract is well recognized and in order for it to maintain this role over long periods it is clear that this reserve must be replenished so that the bird may continue in overall calcium balance.

The difficulties underlying a full understanding of skeletal metabolism in the laying hen are mainly concerned with the problems of how the processes of calcium mobilization and storage are controlled and regulated in relation to shell formation and to the amount of calcium supplied by the diet.

The broad outlines of the changes that occur in the skeletons of female birds in relation to egg production are well understood. As the follicles in the ovary mature the ostrogens they secrete, acting in synergism with androgens, induce the formation of a system of secondary bone in the marrow cavities of most bones in the skeleton. This bone, known as medullary bone, is in the form of fine interlacing spicules which grow out from the endosteal lining of the bone and invade the marrow space. It has been studied in greatest detail in the femur of the pigeon. In this bird medullary trabeculae occupy virtually the whole of the marrow cavity of the femur by the time the first egg is due to be calcified. In the pullet at point of lay, however, medullary bone extends only a short distance from the endosteum. The extent to which the marrow is invaded varies in different parts of the femur from $0.2-0.9 \mathrm{~mm}$ for birds of modern hybrid laying strains, with a mean of $0.5 \mathrm{~mm}$. (STRINGER, I962). At this time the spicules of medullary bone are very thick : as laying continues the spicules invade further into the marrow cavity becoming thinner as they advance. After 6 weeks of lay STRINGER (I962) observed a mean depth of medullary bone of I.I mm (range $0.6-1.9 \mathrm{~mm}$ ) in 6 medium hybrid pullets (fig. $I$ and 2).

During the immediate pre-laying period the total skeletal weight of pullets

(1) Present address : Department of Physiology and Biochemistry, The University, Southampton, So $95 \mathrm{NH}$ (Great Britain). 
increases by $15-20 \mathrm{~g}$ (approx. $20 \mathrm{p}$. IOo), representing the storage of an additional 4-5 $\mathrm{g}$ calcium and it is presumed that this mineral is stored mainly in the medullary bone, although it is possible that the cortical bone also increases in weight during this period. Birds which come into lay precociously are in serious negative calcium
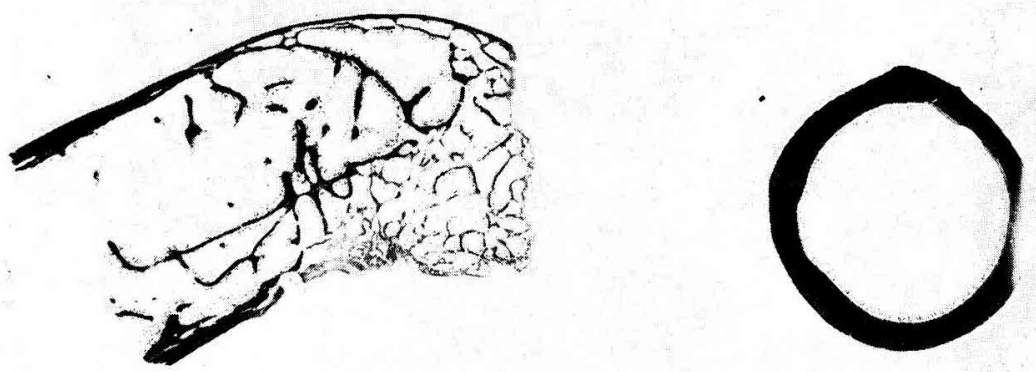

(I)
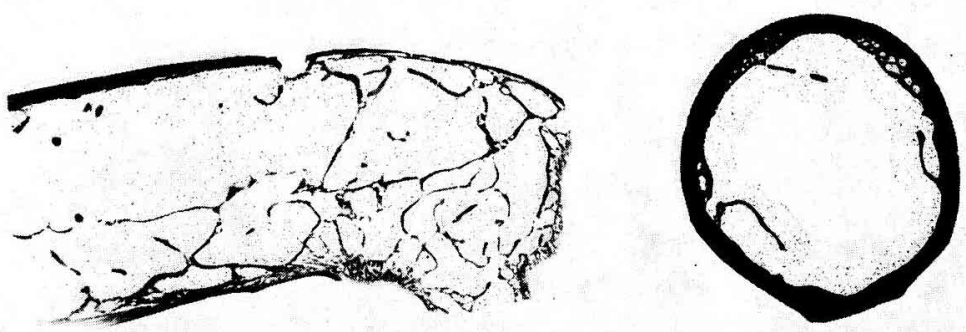

(2)

FIG. I and 2. - Microradiographs $(\times 3,5)$ of longitudinal and transverse sections through the femurs of laying hens, (I) after laying 1 egg (2) after 6 weeks of lay (Sections and microradiographs prepared by Dr Jennifer JowSEY)

balance at the start of egg laying and during the first 6 weeks of production they may lose 20-25 p. Ioo of the amount of skeletal tissue present at point of lay, compared with a loss of approx. 5 p. Ioo in birds whose sexual maturity is retarded by an appropriate light regime during rearing (TAYLOR and MORRIS, I964).

Medullary bone acts as a labile reserve of calcium which is rapidly mobilized when the egg-shell is being calcified. This mobilization is effected by cellular activity in the bone and it is shown most clearly in the pigeon. In this species a clutch consists of only 2 eggs, which are laid on alternate days. Calcification of each shell is accompanied by bone resorption associated with intense osteoclastic activity, and soon after the first egg is laid the bone-resorbing phase gives way to one dominated by bone-formation (BLOOM, BLOOM and MCLEAN, I94I). The cellular changes occurring in medullary bone during shell formation are less well defined in the domestic hen, in which the time interval between the calcification of successive eggs may be only 4-5 hours, instead of 24 hours as in the pigeon (BLoom, Domm, Nalbandov and BLOOM, I958). 
We are currently engaged in a histological study of the changes that occur in medullary bone during the egg-cycle in hens fed a low-calcium diet, using histochemical and radiographic techniques in addition to standard histological procedures, and a preliminary report has been published (BELANGER and TAYLOR, I967). It appears from this work that resorption of medullary bone under the influence of enlarged osteocytes (osteolysis) occurs during egg-shell calcification and that this mechanism is of major significance in the resorptive process.

The osteoclast may not then play such an important part in the destruction of medullary bone as has been accorded to it in the past and one of its main function appears to be that of removing the bone material remaining after the osteolytic process has partially degraded it by organic acids and by proteolytic and other acid hydrolases.

BLOOM et al. (I94I) interpret their observations as indicating that, in the relatively long egg-cycle of the pigeon, phases of bone-destruction (occurring during shell calcification) alternate with phases of bone-formation, but it seems probable that the events occurring in the medullary bone of the fowl during its short eggcycle of 24-26 hours are somewhat different from this. The following proposals based partly on the experiments outlined above seem capable of offering a logical explanation for many of the observations that have been made on the medullary bone of laying fowl :

I. Growth of medullary bone is continuous, although the actual rate of growth may vary depending on the circulatory level of ostrogens and androgens.

2. Growth is from the surfaces of the spicules, which penetrate further into the marrow cavity the longer the bird is in lay.

3. Resorption, as a result of osteocytic osteolysis accompanied or followed by osteoclasis is intermittent and associated with the calcification of the shell. At the start of shell formation resorption occurs mainly in the spicules nearest the centre of the marrow cavity, but as shell formation proceeds resorption extends towards the cortical bone. At any one time, some surfaces of the medullary bone may be undergoing active resorption while adjacent surfaces are growing equally actively.

In birds which lay shell-less eggs medullary bone may advance into the marrow cavity until the latter is virtually obliterated by a very dense and highly-calcified type of bone tissue. The same phenomenon may also be observed in vitamin D-deficient birds, which are laying at a very low rate (unpublished observations). Presumably little or no bone destruction occurs in such birds, while bone formation proceeds normally. Recently, we examined the bones from 6 birds which had been laying shell-less eggs for about 8 months after a surgical operation in which a thread was inserted in their shell-glands (LAKE and GILBERT, Ig64). The mean total skeletal weights of these birds estimated by the method of MORRIS, TAYLOR and BROOKHOUSE: ( 1966 ), and the percentage of ash in the coracoid and in a $\mathrm{r} \mathrm{cm}$ segment of the tibia are given in table I together with corresponding data for unoperated control birds (TAYIOR and GILBERT, unpublished observations).

The next question to be considered is the mechanism by which the resorption of medullary bone is controlled in relation to the calcification of the egg-shell. Most workers in this field have accepted the original suggestion of RIDDLE, RAUCH and SmiтH (I945) that resorption is brought about by a reduction in the level of œstrogen 
circulating in the blood after ovulation. It should be emphasized that this theory was originally put forward to explain the events occurring in the bones of pigeons, in which there is likely to be a substantial reduction after the ovulation of the first follicle and in which the fall in ostrogen following the ovulation of the second follicle

TABLE I

Estimated mean skeletal weights and ash percentages of coracoids and tibias of hens laying shell-less eggs and of control birds ( \pm standard errors)

\begin{tabular}{|c|c|c|c|c|}
\hline & \multirow{2}{*}{ No. birds } & \multirow{2}{*}{$\begin{array}{l}\text { Skeletal weights } \\
(\mathrm{g})\end{array}$} & \multicolumn{2}{|c|}{ Ash percentages } \\
\hline & & & Coracoids & Tibias \\
\hline Experimental $\ldots \ldots \ldots$ & 6 & $\begin{array}{l}93.2(1) \\
\pm \quad 2.57\end{array}$ & $\begin{array}{l}\quad 69.3\left({ }^{1}\right) \\
\pm \quad 0.58\end{array}$ & $\begin{array}{l}72.4\left(^{1}\right) \\
+\quad 0.59\end{array}$ \\
\hline Control $\ldots \ldots \ldots \ldots \ldots$ & 11 & $\begin{array}{r}70.7 \\
\pm \quad 3.18\end{array}$ & $\begin{array}{r}65.5 \\
+\quad 0.12\end{array}$ & $\begin{array}{r}69.0 \\
+\quad 0.81\end{array}$ \\
\hline
\end{tabular}

(1) Significantly greater $(\mathrm{P}<0.001)$ than corresponding control mean.

must be precipitous. The situation in the laying hen is quite different from that in the pigeon, however. At any one time a much larger number of follicles are developing and presumably secreting œstrogen, and it is probable that the fall in plasma œestrogen occurring after ovulation is relatively slight.

However, the main difficulty in accepting the ostrogen-withdrawal theory of medullary bone resorption during shell formation is that it seems incapable of providing the fine control of the process which is clearly being exercised.

It has always seemed to me much more reasonable to assume that resorption of medullary bone during shell formation is controlled by the parathyroid gland stimulated by the fall in the diffusible calcium level of the plasma (TAYLOR, I965). One of the arguments that has been advanced against this theory is that parathyroid hormone does not bring about the same histological changes in medullary bone as occur during shell formation (URIST, I967). However, the only experiment reported in the literature on the histological effects of parathyroid hormone on the bones of laying hens is one in which the dose of hormone was extremely high, $75^{\mathrm{O}-\mathrm{I}}$ ooo U.S. P. units daily for I-3 days (URIst, Deutsch, Pomerantz and McLEan, I960) and the effects of such doses were probably more pathological than physiological. (An injection of only Ioo U. S. P. units produces a rise in the level of plasma calcium in a $2 \mathrm{~kg}$ hen of more than $5 \mathrm{mg} / \mathrm{IOO} \mathrm{ml}$ (HERTELENDY, I962). In any event, the observed changes (detachment of the medullary bone from the cortex) occurred 48 hours after the initial injection of hormone and can thus have little relevance to the changes that occur during the period of shell calcification, which is only 20 hours.

We have recently carried out an experiment in which hens fed a high-calcium diet were injected with parathyroid extract (Ioo U.S. P. units $/ \mathrm{kg}$ body weight) at the time an egg entered the shell gland and pairs of birds were killed after 2, 4, 6 and 
8 hours. The changes observed by conventional histology, by micro-radiography and by alpha-radiography all indicated that the effect of the hormone was to enhance the naturally-occurring changes in the bone cells, the mineral fraction and the organic matrix (TAYLOR and BELANGER, I969). Osteolysis was also stimulated in the cortical bone.

When hens are fed a calcium-deficient diet the amount of medullary bone present in the marrow cavities is maintained while the amount of cortical bone decreases as laying continues (TAYLOR and MOORE, I954). An essential feature of the parathyroid-involvement theory of medullary bone resorption is that, because of its large surface area and high vascularity, medullary bone is more sensitive than cortical bone to parathyroid hormone and the persistence of medullary bone at the expense of cortical bone in calcium-deficient hens appears to conflict with this theory. If medullary bone is resorbed under the influence of parathyroid hormone, why is it not completely destroyed in calcium deficiency when the level of the hormone in the blood is presumably greatly increased? It is not possible to resolve this difficulty at the present time but a reasonable explanation may be offered along the following lines :

I. When a hen is fed a high-calcium diet, there is a relatively small increase in the plasma level of parathyroid hormone during shell calcification, an increase which produces a substantial response in medullary bone but a minimal response in cortical bone.

2. Under conditions of calcium deficiency the rate of secretion of the parathyroid gland is increased to a level at which the response of the cortical bone is greatly increased while the further response of the medullary bone is only slight.

This hypothesis, then, suggests that medullary bone has a threshold-response and a range of response lower than that of cortical bone. It assumes that the growth of new medullary bone proceeds at a steady rate during the early stages of the calcium deficiency (so long as follicles continue to mature), and that this new bone is calcified at the expense of the cortical bone, which is continually being resorbed from the endosteal surface, sometimes resulting in the separation of the medullary bone from the cortex. Some hens fed a low-calcium diet have been found to have medullary bone containing as little as $I_{7}$ p. Ioo ash, compared with a normal content of 4050 p. IOO (TAYLOR and MOORE, I954), and the probable explanation is that, in these birds, the newly-formed medullary bone is poorly calcified, i. e. calcium mobilization from the cortical bone is insufficient for the calcification of both egg-shell and medullary bone - and the former has priority. This situation may be exaggerated by maintaining ovulation - and presumably cestrogen production - in hens fed a calcium-deficient diet by injections of pituitary extracts (TAYLOR, MORRIS and

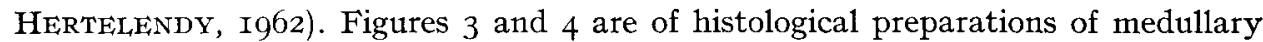
bone from control, high-calcium and of pituitary-injected, low-calcium hens, respectively. Virtually no calcified tissue remains in the latter preparation, which shows a condition of osteomalacia, since large amounts of osteoid are present.

When hens are fed a low-calcium diet they normally cease production after laying 4-8 eggs : follicles stop developing and become atretic, œstrogen production falls, the oviduct regresses and medullary bone is resorbed. These changes can be prevented by injections of extracts of avian pituitary glands and it seems probable 


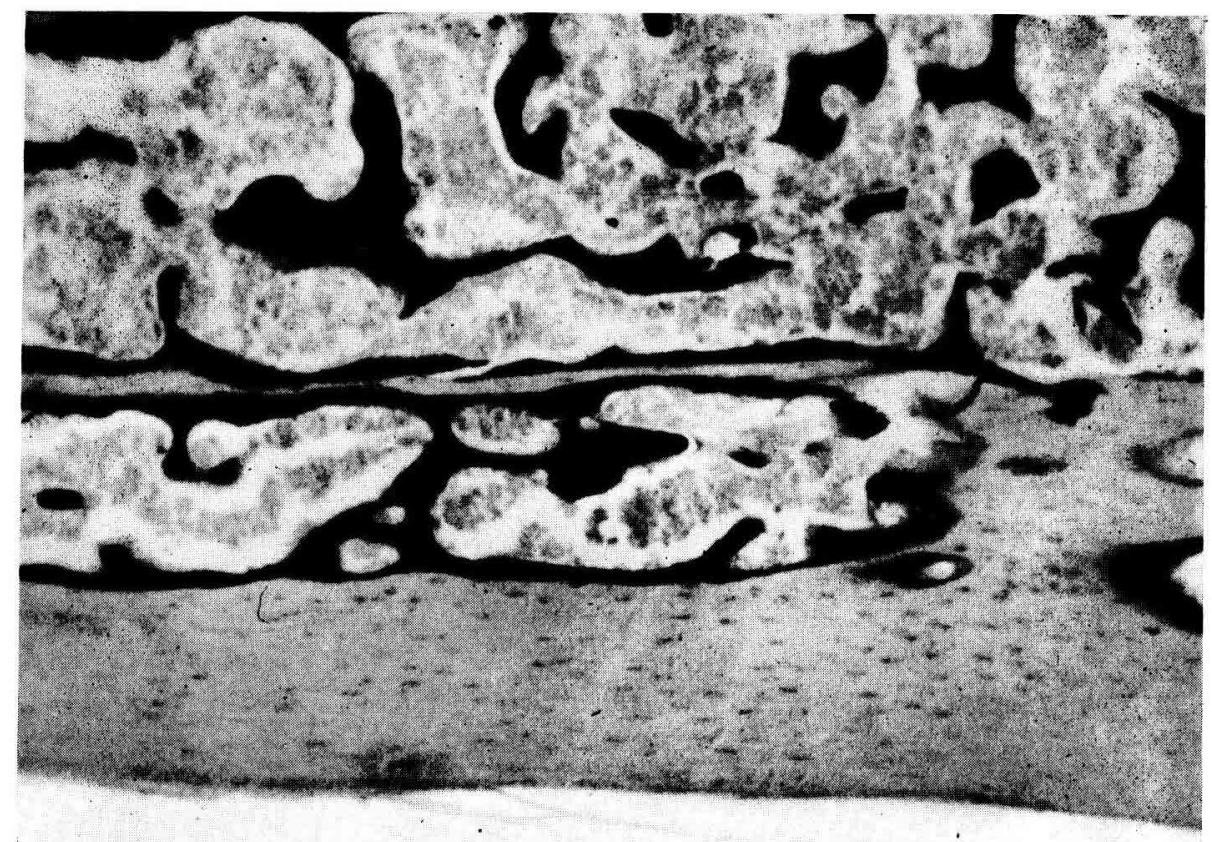

(3)

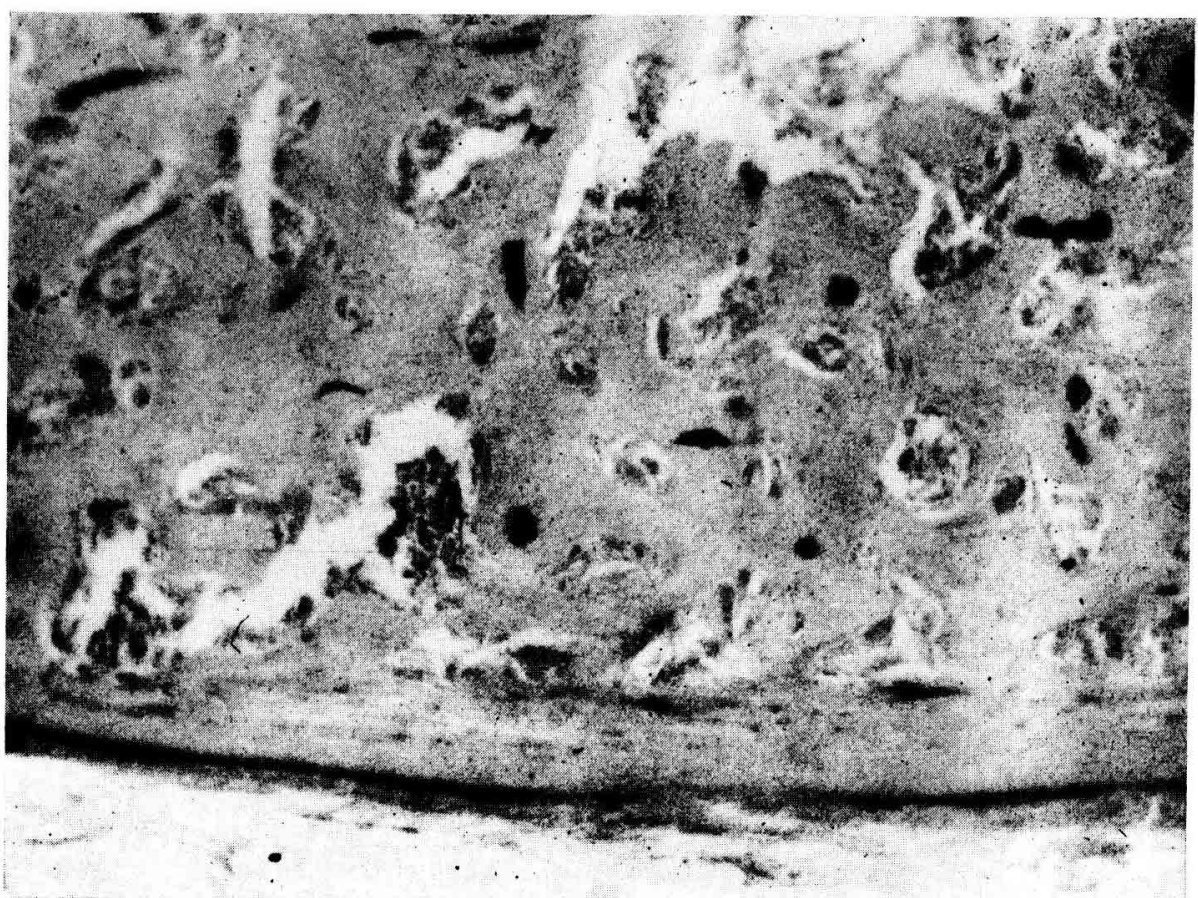

(4)

FIG. 3 and 4 . - Photomicrographs $\left(\times 4^{8)}\right.$ of PAS-Alcian Blue stained sections through the femurs of laying hens, (3) control fed a high-Ca diet, (4) experimental bird fed a low-Ca diet and injected with a crude avian pituitary extract to maintain ovulation.

Note almost complete loss of staining reaction in (4) associated with loss of bone mineral, and the thinness of the cortex

(Sections and photomicrographs prepared by Dr D.-A. Stringer) 
therefore that secretion of gonadotrophins is inhibited in a calcium deficient bird (TAYLOR et al., I962). The mechanism by which the secretion of pituitary gonadotrophins is cut off in calcium-deficiency has not been established, but it has been suggested (TAYLOR, I965) that release of a gonadotrophin-releasing factor from the hypothalamus may be inhibited when the ionic calcium level in the plasma falls below a certain critical level. It is possible that this level may be reached in some birds during shell formation even when a high-calcium diet is fed, in which case the ability of birds to metabolize calcium would be one of the factors concerned in determining the rate and persistence of egg-production. The inhibition of gonadotrophin secretion in calcium-deficient female birds may be looked upon as a protective mechanism preventing excessive depletion of the skeleton, that has developed during the course of evolution in parallel with the habit of laying eggs with highly calcified shells. Its significance for wild birds living in lime-deficient areas, particularly graineating birds, is self evident.

The two major hormones concerned in the regulation of calcium metabolism in mammals are the parathyroid hormone and calcitonin. The significance of the former hormone in laying birds has already been discussed and the possible function of calcitonin will now be considered. In mammals the major source of this hormone is the thyroid and in the pigeon the thyroid is also a fairly rich source. (MOSFIEx, Matrhews, Breed, Galante, Tse and Mac Intyre, I968). In the fowl, however, the thyroid is of relative low potency and the greatest concentration of the hormone is found in the uttimobranchial bodies (COPp, CockcrofT and KUEH, I967).

The effect of calcitonin in mammals is to reduce the level of plasma calcium, probably by inhibiting bone resorption (see FOSTER, I968, for review). The young rat appears to be particularly sensitive to calcitonin, whether from mammals, birds, reptiles or fish, but the young chicken is very insensitive to calcitonin, even to chicken calcitonin, and there have been no reports in the literature of any positive responses to the hormone in this species.

As far as is known, secretion of calcitonin is stimulated only by hypercalcæmia and it is presumably the level of ionic calcium that provides the stimulus. Thus, in the laying hen, secretion of calcitonin would not be expected during shell calcification which is associated with a reduction in the diffusible calcium level of the plasma, and, indeed were it to be secreted at this time it could only impair the process of shell calcification by further lowering the plasma calcium. A possible physiological role for calcitonin in the laying bird could be in minimizing the rise in blood calcium after shell formation is completed, thereby conserving bone and reducing urinary loss of calcium. However, it is not yet known whether or not the laying hen responds to calcitonin, and it is possible that it may be a biochemical vestige which, in avian species, has an endocrine role only in the embryo, in which the blood calcium is maintained at a sub-normal but gradually increasing level during the last week of incubation. At the I4-day stage of incubation the mean level of serum calcium is only 5.I $\mathrm{mg} / \mathrm{IOO} \mathrm{ml}$ (TAYLOR, I963). 


\title{
SUMMARY
}

The endocrine mechanisms by which bone metabolism is controlled and regulated in the laying hen in relation to egg formation are discussed. It is suggested that growth of medullary bone under the combined influence of ostrogens and androgens is continuous in hens laying regularly and that resorption of this bone under the influence of parathyroid hormone is intermittent. Substantial mobilization of cortical bone only seems to occur when the bird is in overall negative calcium balance, when the rate of secretion of the parathyroid is greatly increased. In an acute state of calcium deficiency the skeleton of the bird is protected from further resorption by a mechanism that inhibits the secretion of gonadotrophins by the anterior pituitary, thus stopping egg production and with it the loss of calcium in the form of shell mineral. The physiological role of calcitonin in the laying hen is problematical; it may be a biochemical vestige of significance only in the embryo.

\section{RÉSUMÉ}

\author{
RÔLE DU SQUELETTE DANS LA FORMATION \\ DE LA COQUILIE DE L'OEUF CHEZ I,A POULE
}

Les mécanismes endocriniens qui contrôlent et régulent le métabolisme de l'os chez la poule pondeuse sont discutés en rapport avec la formation de l'œuf. Il est suggéré que, sous l'influence combinée des ostrogènes et des androgènes, la croissance de l'os médullaire est continue chez les poules qui pondent régulièrement et que la résorption de cet os sous l'action de l'hormone parathyroïdienne est intermittente. Une mobilisation substantielle d'os cortical ne semble se produire que lorsque la poule est en bilan calcique négatif, moment où le taux de sécrétion de la parathyroïde est largement augmenté. En cas de déficience calcique aiguë, le squelette de l'oiseau est protégé contre une résorption supplémentaire grâce à un mécanisme qui inhibe la sécrétion de gonadotrophines par l'hypophyse antérieure, stoppant ainsi la production d'œufs et, par conséquent, la perte calcique due à la coquille. Le rôle physiologique de la calcitonine est problématique chez la poule pondeuse ; il se réduit peut-être à un vestige biochimique n'ayant de signification que chez l'embryon.

\section{REFERENCES}

Belanger L. F., TAYlor T. G., 1967. The mechanism of bone resorption in laying hens. Anat. Rec. 157, 2 II-2I2.

Bцоом W., Вцоом M. A., McLean F.C., I94I. Calcification and ossification. Medullary bone changes in the reproductive cycle of female pigeons. Anat. Rec., 81, 443-475.

Bloom M. A., Domm L. V., Nalbandov A. V., Bloom W., i958. Medullary bone of laying chickens. Amer. J. Anat., 102, 4II-453.

Copp D. H., Cockcroft W., KUEH Y., I967. Ultimobranchial origin of calcitonin. Hypocalcemic effect of extracts from chicken glands. Can. J. Physiol. Pharmac., 45, Io95-Iog9.

Foster G. V., I968. Calcitonin. A review of experimental and clinical investigations, Postgrad. med. J., 44, 4II-422.

HERTELENDY F., I962. Biochemical studies on the tissues of the domestic forel in relation to reproduction. Ph. D. Thesis, University of Reading.

Lake P. E., Gilbert A. B., I964. The effect on egg production of a foreign object in the lower oviduct regions of the domestic hen. Res. vet. Sci., 5, 39-45.

Morris T. R., TAYlor T. G., Brookhouse J. K., I966. The prediction of skeletal weight from the weights of sample bones. Br. Poult. Sci., 7, I53-157.

Moseley J. M., Matthews E. W., Breed R. H., Galante L., Tse A., Mac Intyre I., I968. Ultimobranchial origin of calcitonin. Lancet (I), Io8-1 Io.

Riddee O., Rauch V. M., Smith G. C., 1945. Action of estrogen on plasma calcium and endosteal bone formation in parathyroidectomized pigeons. Endocrinology, 36, 4I-47. 
Simkiss K., r96r. Calcium metabolism and avian reproduction. Biol. Rev., 36, 321-367.

Simkiss K., 1967. Calcium in reproductive physiology, 155-197, Chapman and Hall, London.

Stringer D. A., I962. The chemistry and physiology of bone. Ph. D. Thesis, University of Reading.

TAYLOR T. G., r963. Calcium and magnesium in the blood and bones of chick embryos. Biochem. J., 87, 7 p.

TAYlor T. G., I965. Calcium-endocrine relationships in the laying hen. Proc. Nutr. Soc., 24, 49-54.

Taylor T. G., Belanger L. F., I969. The mecanism of bone resorption in laying hens. Calc. Tiss. Res., 4, I62-I73.

TAYlor T. G., Moore J. H., r954. Skeletal depletion in hens laying on a low calcium diet. Br. $J$. Nutr., 8, I I 2-1 24.

TAYLOR T. G., Morris T. R., I964. The effect of early and late maturity on the skeletons of pullets. IVorld's Poult. Sci. J., 20, 294-297.

Taylor T. G., Morris T. R., Hertelendy F., I962. The effect of pituitary hormones on ovulation in calcium deficient pullets. Vet. Rec., 74, 123-125.

Taylor T. G., Strivger D. A., I965. Eggshell formation and skeletal metabolism. In Avian Physiology, Second Ed,, by Sturkie P. D. Comstock Publishing Associates. Cornell Univ. Press, Ithaca, N. Y., p. 485-50I.

URIST M. R., I967. Avian parathyroid physiology : including a special comment on calcitonin. Amer. Zool., 7, 883-895.

Urist M. R., Deutsch N. M., Pomerantz G., McLean F. C., x960. Interrelations between actions of parathyroid hormone and estrogens on bone and blood in avian species. Amer.J. Physiol., 199,85I85.5 . 